\title{
Benign Paranasal Sinus Neoplasm
}

National Cancer Institute

\section{Source}

National Cancer Institute. Benign Paranasal Sinus Neoplasm. NCI Thesaurus. Code C8532.

A non-metastasizing neoplasm that arises from the paranasal sinuses. Representative examples include Schneiderian papilloma and salivary gland-type adenoma. 